Article

\title{
The Impact of Global Value Chain Participation on Sectoral Growth and Productivity
}

\author{
Halit Yanikkaya ${ }^{1, *(\mathbb{D})}$ and Abdullah Altun 2 (1) \\ 1 Department of Economics, Gebze Technical University, Gebze/Kocaeli 41400, Turkey \\ 2 Informatics and Information Security Research Center, The Scientific and Technological Research Council of \\ Turkey, Gebze/Kocaeli 41470, Turkey; abdullah.altun@tubitak.gov.tr \\ * Correspondence: halityanikkaya@gtu.edu.tr; Tel.: +90-262-6051-420
}

Received: 14 March 2020; Accepted: 10 June 2020; Published: 13 June 2020

\begin{abstract}
This study investigates the impact of participation in global value chains (GVCs) on sectoral value-added and total factor productivity growth (TFP) for two different time periods of 1995-2011 and 2005-2015. In addition to the commonly used participation indices, we also calculate lesser known measures of backward and forward participation indices, as suggested by the OECD. Our Generalized Method of Moments (GMM) estimations for the full sample indicate that sectors with higher GVC participation experience much higher output and TFP growth, especially for the period 1995-2011. Overall, our results imply that there have been decreasing gains from GVC participation in the later period. Note that our estimates for both output and TFP growth are very much similar. This means that participation in GVCs promotes not only output growth but also productivity growth across sectors. Considering the parameter heterogeneity, we repeat our estimations for manufacturing and services separately. Although for the earlier period both the manufacturing and services sectors benefit from more participation in terms of higher output and productivity growth, only the manufacturing sector experiences higher productivity growth from more participation for the period 2005-2015. Relatively less significant and smaller estimates for the later period covering the latest global crisis imply that participation in GVCs fails to bring satisfactory gains to countries and sectors.
\end{abstract}

Keywords: participation in GVCs; sectoral value-added growth; sectoral TFP growth

\section{Introduction}

Global value chains (GVCs) are among the core realities of the contemporary global economy. International trade is increasingly driven by global value chains. The fragmentation of production processes within GVCs have led to the emergence of borderless production systems [1]. The goods and services start to consist of value-added from various countries and sectors in a level never seen before. The theoretical literature recently has concluded that countries can benefit from participation in GVCs through multiple channels, such as productivity spillovers based on intermediate trade, learning by interacting, accessing new markets and upgrading for positioning in higher value-added activities. For example, The World Development Report 2020 argues that finer international division of labor-so called hyper-specialization-and durable firm-to-firm relationships lead to technology diffusion and access to efficient capital and inputs [2]. Moreover, Fessehaie and Morris [3] report that participations in GVC have critical roles in achieving Sustainable Development Goals (SDGs) in income and employment generation, upgrading into better products or processes, and rarely more sophisticated functions. Knowledge diffusion driven by GVCs is also vital for both developed and developing countries to achieve sustainable growth [4]. More specifically, participation in GVCs is the key driver for achieving the majority of the targets of the SDG 9, which refers to building resilient infrastructure, promoting inclusive and sustainable industrialization and fostering innovation by enabling accession to production 
opportunities, finance and markets, and offers upgrading potential for skills, technology, hard and soft infrastructure and institutions. Actually, governments and multinational development organizations, having a vision of balanced approach on competitiveness, inclusiveness and sustainability, regard the GVCs as the key elements of their development strategies [5]. An effective facilitation from the GVCs can only be possible by benefiting from both macroeconomic dimensions, such as growth and productivity spillovers, and relative micro dimensions, such as distributing these gains equally in the economy. Therefore, our study accentuates the macroeconomic dimensions of the growth and productivity impacts of GVCs to investigate whether GVCs can sustain their growth and productivity promoting roles. Since then, a number of studies question the benefits of value chains, especially after the latest global financial crisis. The transmission of demand shocks is much more rapid for the regions relatively more integrated to GVCs by spreading through intermediate trade channels along the chains [6]. The negative impact of a shock on final demands is also exacerbated for more integrated sectors, which is called the "bullwhip effect". Higher volatility in demand faced by intermediate suppliers leads them to raise their inventories to cope with this uncertainty [7]. Recently, both Rodrik [8] and Fagerberg et al. [9] criticize the contribution of participation in value chains on output and productivity growth.

Whether the participation in GVCs really brings growth and total factor productivity (TFP) gains for countries or sectors is an important empirical question. This question is also worth studying, especially after the substantial slowdown in value chains after the 2008 crisis. There is a lack of disaggregated studies, such as industry-level analysis, mostly due to data availability. Our study is an important attempt to close this gap by providing new industry-level evidence by using the comprehensive industry-level data from OECD Trade in Value Added (TiVA) and European Union level analysis of capital (K), labor (L), energy (E), materials (M) and service (S) inputs (EU KLEMS). This paper initially calculates sectoral-level GVC participation indices based on the two different approaches suggested by OECD [10] and Koopman et al. [11]. We thus have two different pairs of participation indices. Conventional measures mainly focus on measuring value-added in trade flows. Because these trade activities continue to move until reaching to final demand, these measures still face double counting risks. However, final demand-based measures enable us to examine value-added levels of countries in final demands at the end after all. One of the main innovations of this paper is to employ final demand-based GVC participation indices in a sectoral-level in the empirical analysis. To the best of our knowledge, this is the first study to investigate the effects of participation rates measured based on final demand, mainly developed by OECD [10], on output and productivity growth. We believe that it is important to employ both types of participation measures not only for the descriptive purposes but also for the empirical purposes.

Another innovation of this study is to examine the impact of sectoral participation on output and total factor productivity growth by combining datasets from EU KLEMS and two versions of OECD TiVA. Our dynamic panel data estimations for the full sample show that all four GVC participation indices have significantly positive impacts on both sectoral value-added and TFP growth for the earlier period. In the later period, these significant and positive effects are mostly available, but their magnitudes and significance levels are substantially lower. Moreover, given the potential parameter heterogeneity for different sub-sectoral categories, we also estimate the regressions for manufacturing and services sectors separately. Overall, our results indicate that participation in GVCs benefits not only manufacturing but also services sectors, especially for the earlier period. Therefore, our results are consistent with the argument that the output and productivity benefits of GVCs decrease after the global crisis.

Section 2 discusses the relevant literature on the participation in global value chains. The data and estimation model are discussed in Section 3. Section 4 presents the empirical results. Section 5 concludes the paper. 


\section{Literature Review}

In an earlier work, Hummels et al. [12] introduce a measure for vertical specialization in world trade by calculating the import content of exports. Their measure basically refers to a backward participation in GVCs, but it actually contains severe double counting problems. By employing their approach for measuring participation in GVCs, Koopman et al. [11] propose a GVC participation index as a sum of the share of foreign value-added in gross domestic exports and the share of domestic value-added in gross foreign exports. These two concepts proposed by Koopman et al. [11] as shares of gross exports are primarily adopted by scholars, and then, become the most known measures of backward and forward GVCs participation. However, significant double counting problems are still available, especially sectoral-level calculations by this way as we mentioned above. Thus, OECD [10] suggests a new set of GVC participation indices, which are different from the previous OECD reports. OECD [10] specifically refers the share of domestic value-added used in production for foreign final demand as a forward participation in GVCs and the share of foreign value-added in domestic final demand as a backward participation in GVCs.

It is important to clarify some points for evaluating these two kinds of participation indices. Final demand-based participation indices are relatively more comprehensive indices compared to the measures as shares of gross exports. For example, for a forward participation index based on final demand measures, how many times domestic value-added of a country crossed borders until reaching to a final demand of other countries does not matter. Domestic value-added of a country may directly be exported as final goods and services by crossing borders just once. Alternatively, domestic value-added may be embodied in foreign intermediate trade to other countries and re-exported then. The last case means that domestic value-added crosses borders two or more times. For a final demand-based backward participation, foreign value-added may cross borders only once if it is totally consumed as final goods and services within a country. Alternatively, foreign value-added may cross borders more than once by being embodied in an intermediate trade and re-exported again. However, considering gross exports-based indices, both backward participation as a foreign value-added in domestic exports and forward participation as a domestic value-added in foreign exports are reflecting border crossing at least twice. With these characteristics, gross exports-based participation indices are a sub-group of final demand-based measures, and thus, show a more complex participation in GVCs. Wang et al. [13] define a new pair of GVC participation indices regarding the simplicity and complexity of GVCs by separating non-GVC activities and considering the number of border crossings. If value-added cross borders once, then participation is simple and if value-added cross borders more than once, then participation is complex. Overall, these two different kinds of indices are not substitutes, but rather they are more likely to be complementary measures of GVC participations.

Given the widely debated deficiencies in gross trade statistics, OECD TiVA database is among the revolutionary attempt for decomposition of contemporary gross trade flows into value-added contents [14]. Many organizations and researchers report the descriptive statistics of these new trade measures, including participation indices; empirical studies analyzing the output growth and/or TFP growth impacts of participation indices are less available though.

Available empirical studies are mostly country-level studies. These studies generally report the positive impacts of participation on output and productivity growth. For example, Yanikkaya and Altun [15] empirically estimate the impact of participation in GVCs on TFP growth for the years 1995-2014 by using OECD-WTO TiVA variables. Their results indicate the significantly positive results for forward participation and significantly negative results for backward participation for the full sample. By using the Eora Multi-Regional Input-Output (MRIO) database, Ignatenko et al. [16] calculate both forward and backward linkages as shares of gross exports for 189 countries for the years 1990-2013 and find the positive impact of participation in GVCs on income per capita and productivity. By using the same database for 125 countries and the period of 1997-2013, Fagerberg et al. [9] report that GVC participation fails to raise output growth. Their results also imply that small countries and countries with low capabilities are in a disadvantageous situation to benefit from value chains. Finally, 
Formai and Caffarelli [17] investigate the impact of country-level backward participations on sectoral TFP and labor productivity growth for 50 countries for the decade averages of 1990 to 2009. They find the positive effects of the participation in GVCs on TFP and labor productivity for the sectors with long and wide production chains of countries specialized in importing intermediate goods.

Sectoral-level empirical studies on the impacts of global value chain participation on output growth and productivity growth are relatively limited. There is also a strand of the literature studying the determinants of GVC participation, see for example, Kowalski et al. [18] and Ignatenko et al. [16]. By employing World Input-Output Database (WIOD) and OECD Inter-Country Input-Output (ICIO) tables for the years 1995-2011, these studies generally report that participation in GVCs, as in Koopman et al. [11], raises value-added and productivity growth. For example, Kummritz [19] investigates the relationship between GVC participation and domestic value-added in sectoral levels for 20 industries of 50 countries for the years 1995, 2000, 2005, and 2008. He shows the positive impact of GVC participation on domestic value-added and this impact is significant only for middle- and high-income countries. Constantinescu et al. [20] analyze the relationship between participation in GVCs and labor productivity. They undertake analysis for 13 sectors in 40 countries over 15 years. They conclude that participation in GVCs, particularly backward participation has positive impact on labor productivity. Similarly, Kordalska et al. [21] provide estimations for 20 industries (as 13 manufacturing and 7 services industries) of 40 countries. They estimate the significantly positive results of backward participation mainly for manufacturing industries.

Recently, Wang et al. [13] evaluate the impact of GVC participation on growth by employing their new participation indices for simple and complex GVC activities. In their empirical analysis, they utilize the data from WIOD for 44 countries and 56 industries for the years 2000-2014. They divide their data into four sub-periods, such as fast growth period (2002 to 2008), global financial crisis (2009), after-crisis recovery period (2010 and 2011) and the growth slow down period (2012-2014). They estimate significantly positive results mainly for the complex GVC participation for the full sample and manufacturing when they estimate for the period 2002-2008 and 2010-2011 together and separately. In estimated results for the 2009 period, the picture totally changes, and they estimate negative significant coefficients for all trade-related production activities, including simple and complex GVC participation. For the last period after 2012, estimations do not seem to be significant. When they conduct their estimations by income level, they estimate much favorable coefficients for the GVC participation of advanced economies.

Based on the literature review above, this study basically tests the following two hypotheses. First hypothesis is "whether participation in GVCs measured by two different methods really brings output and productivity growth". The second hypothesis is "unlike the empirical studies above since we also employ the latest version of TiVA, whether the impacts found in the earlier period continue or change in the later period".

\section{Model and Data}

This study employs three main datasets: September, 2017 release of EU KLEMS (revised July 2018) [22] (ISIC Rev.4/Nace Rev 2), and two versions of TiVA dataset from the OECD TiVA 2016 (2018) using ISIC Rev.3 (Rev.4) [14,23] for calculation of GVC participation indices and sectoral outputs. We utilize R software (see R Core Team [24]) to combine these large datasets of EU KLEMS [22], with TiVA 2018 and 2016 editions by matching overall industries. Considering the significant differences between TiVA 2016 and 2018 editions, we choose to undertake estimations for the years 1995-2011 (TiVA 2016 edition) and 2005-2015 (TiVA 2018 edition) separately. We employ exchange rates from Eurostat in order to get comparable data from TiVA and KLEMS [25]. In addition to these industry-level measures, we also obtain several country-level variables from the World Development Indicators (WDI) [26] and the World Governance Indicators (WGI data are available both at www.govindicators.org and https://datacatalog.worldbank.org/dataset/worldwide-governance-indicators (accessed on $6 \mathrm{March}$ 2019)) (WGI) [27]. 
Although the exact same variables are available both in 2016 and in 2018 versions of TiVA, regarding the magnitudes of variables, there are notable differences between them. TiVA 2016 is derived from Inter-Country Input-Output (ICIO) tables based on SNA 1993 (1993 System of National Accounts), whereas TiVA 2018 is derived from ICIO tables (2018 edition), based on SNA 2008 statistics [14]. Regarding this, we chose not to combine the 2016 version of TiVA (from 1995 to 2011) and the 2018 version of TiVA (2005-2015) for accessing a larger dataset covering the years from 1995-2015. Thus, we consider variables from two different versions separately in our panel data model. Variables from TiVA 2016 are available for 21 industries for the years 1995-2011 and TiVA 2018 are available for 28 industries for the years 2005-2015 in our analysis.

Although the EU KLEMS database has a time span of 1970-2015, data for most countries are mostly available for the years between 1995 and 2015 for this version. It covers 34 individual industries and 8 aggregates. However, there are limits in industry coverage for capital variables of some countries such as Greece, Ireland, Portugal, Bulgaria, Cyprus, Estonia, Hungary, Latvia, Lithuania, Poland, and Romania [22]. Similarly, while the 2018 version of TiVA includes 36 unique industrial sectors and 18 aggregates, the earlier version includes 34 unique industrial sectors and 18 aggregates. As long as we manage to match these datasets by unique sectors, we do it for each industry, and then, choose not to include related aggregates. If not, we then take aggregates of relevant sectors. Note that if we take an aggregate, we then drop related subsectors to eliminate double counting. Appendix A Table A1 reports the industry matching for these datasets. The 2018 version of TiVA is the last version of TiVA releases after the 2016 version and covers 64 economies (in addition to the previous country coverage, Kazakhstan is added to TiVA_2018 country list) (see Appendix A Table A2). The TiVA database covers all countries of EU KLEMS sub-datasets. Thus, our combined dataset includes $26 \mathrm{EU}$ countries and the USA (the EU KLEMS actually covers 28 EU countries and the USA, but data for Belgium and Croatia are missing in "All Capital Input Files").

\subsection{Participation Indices}

As discussed above, we calculate two different sets of participation indices from both TiVA 2016 and TiVA 2018 separately based on the methods in Koopman et al. [11] and OECD [10]. We thus have two different pairs of participation indices. As reviewed above, the most common measures of GVC participation, as in Koopman et al. [11], use sectoral export shares in the denominator. For calculation of industry-level backward participation, T1BWPSecX (T2BWPSecX for TiVA 2018), it is necessary to use two variables from two different data files: EXGR_FVA $A_{c, W O R, i, t}$ and $E X G R_{c, p, i, t}$. EXGR_FVA $A_{c, W O R, i, t}$ shows the amount of foreign value-added in exports of industry $i$ in country $c$. $E X G R_{c, p, i, t}$ shows the exports in country, partner, industry and year dimensions. For the first variable, data are just available for "World" in a partner column, but for the second one, we need to filter the data by choosing partner as "World". Then, the formula for the participation index is:

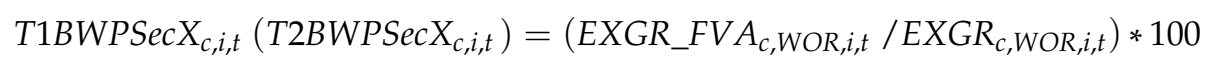

For the calculation of industry-level forward participation, T1FWPSecX (T2FWPSecX), again, it is necessary to use two variables in different csv files: EXGR_DVAFXSH $H_{c, W O R, i, t}$ and $E X G R_{c, p, i, t}$. For the first variable, again, only partner is "World". It shows the domestic value-added embodied in foreign exports as share of gross exports. Since we need to calculate our participation indices as shares of sectoral exports, we need to multiply each variable with its country's gross exports. We can then divide each outcome by sectoral exports. For accessing country-level exports, $E X G R_{c, p, i, t}$ should be filtered as $p=$ WOR (WLD) (World) and $i=$ CTOTAL (DTOTAL) (Total). For calculating sectoral exports, just filtering these data as $p=W O R(W L D)$ (World) is enough. Thus, our formula for forward participation as follows:

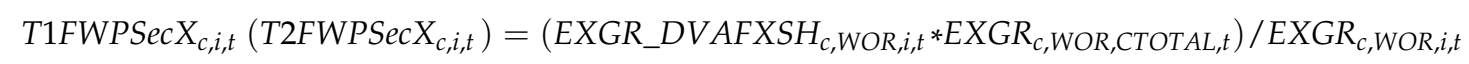


As a result of the above formulation, GVC participation indices for some industries are much higher than 100 percent. This is an expected result because value-added of these industries are exported indirectly by being embodied in the exports of other industries [13]. Based on our personal communication with the OECD staff on this matter, they also confirm that there would be significant double counting problems if indicators were used in that way and they recommend that using final demand-based participation indices has always been better to avoid double counting problems. Therefore, as the second sets of GVC indices, OECD [10] reports GVC participations differently from the previous OECD reports. The share of foreign value-added in domestic final demand is considered as the backward participation and the share of domestic value-added used in production for foreign final demand is considered as the forward participation.

Backward participations in GVCs from both TiVA 2016 and TiVA 2018 editions are measured based on the $F D_{-} V A S H_{c, p, i, t}$ variables. This variable shows the share of value-added of partner countries $(p)$ for each industry of origin $(i)$ in the total final demand in country $c$. Source country includes country $c^{\prime} s$ domestic value-added as well. T1BWPFD (T2BWPFD) for TiVA 2018 is our notation for the backward participation index based on OECD [10]. Thus, our formula for calculation is:

$$
T 1 B W P F D_{c, i, t}\left(T 2 B W P F D_{c, i, t} \text { for TiVA 2018) }=F D_{-} V A S H_{c, W O R, i, t}-F D_{-} V A S H_{c, D X D, i, t}\right.
$$

when choosing partner as WOR or WLD (World), the value is 100 percent. If we choose partner as DXD (Domestic), it shows the value-added share of domestic industry in domestic final demand. Thus, the remaining percentage gives us the backward participation.

For the calculation of forward participation based on OECD [10], we use VALUX_FFDDV $A_{c, W O R, i, t}$ and VALU_FFDDVA $A_{c, W L D, i, t}$ variables for TiVA 2016 (T1FWPFD) and for TiVA 2018 (T2FWPFD), respectively. Variables based on TiVA for industry $i$ in country $c$ show the share of domestic value-added from industry $i$ for meeting foreign final demand. These files also have dimensions for partners, but just WOR (World) is available as a partner. Thus, simply sub-setting and changing the name of the columns are sufficient for us.

\subsection{Estimation Model}

An empirical growth model commonly used in the literature is employed to analyze the effects of participation in GVCs on sectoral value-added growth and total factor productivity (TFP) growth separately. The data employed in our analysis are industry-level data including several measures of country-level data. The model has the following general form:

$$
Y_{c, i, t}=\alpha_{0}+\alpha_{1} L . Y_{c, i, t}+\alpha_{2} \text { lcapstockpw }_{c, i, t}+\alpha_{3} \text { l_labprodp }_{c, i, t}+\alpha_{4} G V C \text { participation } \text { cli,t }_{c}+\alpha_{5} X_{c, t}+\varepsilon_{c, i, t}
$$

where $Y_{c, i, t}$ is the dependent variable ( $c$ : country, $i$ : industry, and $t:$ time) and represents measures of value-added and total factor productivity growth. L. $Y_{c, i, t}$ represents the first lag of the dependent variable $\left(Y_{c, i, t}\right)$. We also employ sector-level capital stock and labor productivity measures. lcapstockpw $w_{c, i, t}$ is the log value of capital stock per worker and l_labprodpw $w_{c, i, t}$ is the log value of labor productivity (value-added per worker). The data source for the last three variables is EU KLEMS (ISIC Rev.4/ Nace Rev 2). GVC participation $_{c, i, t}$ represents two different types of backward GVCs participation indices and two different types of forward GVCs participation indices as pairs. Data sources for the participation indices are 2018 edition of TiVA database of OECD [14] and its 2016 edition [23]. $X_{c, t}$ is a vector of country-level control variables having country and year dimensions such as log values of GDP per capita, fertility rates and the rule of law index. Data source for the first two measures is World Development Indicators of World Bank [26] and the last one is World Governance Indicators of World Bank, produced by Kaufmann and Kraay [27]. Table 1 provides the summary statistics. 
Table 1. Summary Statistics.

\begin{tabular}{|c|c|c|c|c|}
\hline & \multicolumn{2}{|c|}{ All Sectors } & Manufacturing & Services \\
\hline Variables & \# of obs. & \multicolumn{3}{|c|}{ Mean Values } \\
\hline Total factor productivity (TFP) growth (\%) & 5677 & 1.047613 & 1.450553 & 1.09291 \\
\hline Value-added growth $(\%)$ & 14,969 & 2.115758 & 1.797285 & 2.751867 \\
\hline Capital stock p.w. (constant USD) & 7505 & $1,252,043$ & $1,316,413$ & $1,360,608$ \\
\hline Labor productivity (constant USD) & 12,846 & $153,881.4$ & $156,682.4$ & $162,409.8$ \\
\hline GDP per capita (constant USD) & 14,424 & $31,266.83$ & & \\
\hline Fertility rates $(\%)$ & 14,424 & 1.549277 & & \\
\hline \multirow[t]{2}{*}{ Rule of law $(-2.5:+2.5)$} & 13,844 & 1.14161 & & \\
\hline & \multicolumn{4}{|c|}{ TiVA 2016} \\
\hline Backward participation_OECD & 9860 & 41.50253 & 62.58587 & 19.3982 \\
\hline Forward participation_OECD & 9860 & 37.48999 & 57.72237 & 19.0915 \\
\hline Backward participation_Koopman & 9423 & 24.91375 & 36.51693 & 12.25939 \\
\hline \multirow[t]{2}{*}{ Forward participation_Koopman } & 9423 & 116.6469 & 67.79084 & 190.7003 \\
\hline & \multicolumn{4}{|c|}{ TiVA 2018} \\
\hline Backward participation_OECD & 8624 & 39.49246 & 61.03065 & 23.87213 \\
\hline Forward participation_OECD & 8624 & 37.05055 & 56.146 & 24.84465 \\
\hline Backward participation_Koopman & 8252 & 23.96507 & 35.6194 & 14.76673 \\
\hline Forward participation_Koopman & 8252 & 78.22425 & 147.0036 & 13.48307 \\
\hline
\end{tabular}

Notes: See the text above for data definitions and sources.

Regarding the participation rates, Table 1 reports that common measures of backward participation rates are calculated considerably lower than OECD-type backward participation rates. However, the reverse is true for forward participation rates. In some cases, the differences are extremely large, such as by a factor of 10 for forward participation indices for services. These huge differences could be a source of unreliable results for especially common indices.

\section{Empirical Results}

The empirical model presented above is estimated for the participation indices for the years 1995-2011 from TiVA 2016 edition and for the years 2005-2015 from TiVA 2018 edition. We estimate the model by using the system GMM method. GMM estimators are frequently employed in the literature to deal with a number of problems such as endogeneity, heteroscedasticity, overidentification, and validity. For example, Baum et al. [28] state that heteroscedasticity is an omnipresent problem in empirical works and using GMM is a more efficient way of handling the heteroscedasticity problem than the instrumental variable (IV) estimator. The first GMM estimator was developed by Arellano and Bond [29], known as Difference GMM, employing instruments as the lags in differences. The system GMM estimation method was later introduced by Arellano and Bover [30] and Blundell and Bond [31] to deal with the number of issues mentioned above and efficiency of parameters. The system GMM models combine the usual equation in first differences using lagged levels as instruments, with an additional equation in levels, using lagged first differences as instruments. All GMM estimations are carried out using the xtabond2 package in Stata (see Roodman [32]). In all estimations, AR(2) tests are insignificant which are an important indicator for the validity of system GMM results. This means that there is no autocorrelation in first difference levels of $\mathrm{AR}(2)$. While considering autocorrelation in GMM, the validity of instruments is tested with the Hansen test. Baum et al. [33] argue that the Hansen $J$ is used test to overidentifying restrictions, which makes the researcher more confident about the appropriateness of the instrument set. In order to deal with instrument proliferation, we retain the number of instruments close to the number of country-sectors in our panel by limiting the lags used in the "gmmstyle" option. The number of groups should be more than or equal to the number of instruments and we test the validity of instruments with the Hansen test. Hansen test statistics with high $p$ values (insignificant statistics) in our tables suggest that the models are correctly 
specified, considering that there is no evidence of correlation between instruments and errors for all of the specifications.

\subsection{Sectoral Value-Added Growth}

Table 2 reports the system GMM estimations for sectoral value-added growth. The statistically significant and negative estimated coefficients on the lagged dependent variable imply that sectors with an initially lower output growth will experience higher growth, especially for the later period. Income per capita across countries leads to lower value-added growth, which is a sign of convergence among outputs. Moreover, higher labor productivity is positively associated with output growth. The positive role of the better maintenance of rule of law on output growth becomes much clear in the later period.

Table 2 also reports the GMM estimation results for the impact of backward and forward GVC participation on sectoral value-added growth. We also estimate the same set of regressions in all tables without country control variables. The estimation results are qualitatively similar. Due to the space considerations, these estimations are not reported, but are available upon request. The significantly and positively estimated coefficients on four different measures of GVC participation for the full sample for TiVA 2016 indicate that both backward and forward GVC participation promote sectoral value-added growth for this period. These results clearly indicate that sectors with higher participation in global value chains experience much better performance.

The reported t-statistics are based on robust standard errors; The Hansen test is a test of overidentification restrictions. Under the null hypothesis, the test statistic is distributed as a chi-squared in the number of overidentifying restrictions and p-values are presented. System GMM results are two-step estimates.

The two-step standard errors are computed in accordance to the Windmeijer [34] finite-sample correction.

All sector-level variables are regarded as endogenous or predetermined variables and their five lags are used as instruments for the former period (eleven lags for the latter period). For the manufacturing and services regressions, lags used in the "gmmstyle" option ranges between one and four.

Country-level variables and time dummies are considered as exogenous.

The positive impacts remain mostly significant in the later period. Although the estimated coefficients are statistically significant and positive, they have much lower estimated coefficients for sectoral value-added growth, except for the forward participation index based on Koopman et al. [11]. The insignificantly estimated coefficient of Koopman et al. [11]-based forward participation index indicates that countries do not benefit from relatively more complex forward GVC participation activities in the later period. The relatively lower effects of GVC participation for the later period could be the consequence of global output slowdown.

One can argue that the estimated coefficients for participation levels could vary between manufacturing and services because the ways in which their integration into the global economy are considerably different. We thus re-estimate our regressions for manufacturing and services separately. Sectors employed in the estimates for services ( 9 sub-sectors) and manufacturing ( 9 sub-sectors) for TiVA2016 and for services (14 sub-sectors) and manufacturing (10 sub-sectors) for TiVA 2018 are listed in the last column of Table A1. For manufacturing, we estimate the significant positive impact of all GVC participation indices, except forward participation index based on Koopman et al. [11] for TiVA 2016. For services, all indices except backward participation based on Koopman et al. [11] are significantly positive. Our results indicate that participation in GVCs is measured as in OECD [10] and has a much more significant effect on output growth. For the later period, none of the estimates are significant for both manufacturing and services. 
Table 2. Estimation Results for the Sectoral Value-Added Growth.

\begin{tabular}{|c|c|c|c|c|c|c|c|c|}
\hline & \multicolumn{4}{|c|}{ TiVA 2016} & \multicolumn{4}{|c|}{ TiVA 2018} \\
\hline & \multicolumn{4}{|c|}{ All Sectors } & \multicolumn{4}{|c|}{ All Sectors } \\
\hline & (1) & $(2)$ & (3) & (4) & (1) & (2) & (3) & (4) \\
\hline VARIABLES & BP_OECD & FP_OECD & BP_K & FP_K & BP_OECD & FP_OECD & BP_K & FP_K \\
\hline Lagged VA growth & $\begin{array}{l}-0.0792 \\
(-0.918)\end{array}$ & $\begin{array}{l}-0.0847 \\
(-0.996)\end{array}$ & $\begin{array}{l}-0.0900 \\
(-1.078)\end{array}$ & $\begin{array}{l}-0.0906 \\
(-1.066)\end{array}$ & $\begin{array}{c}-0.119^{* * *} \\
(-3.052)\end{array}$ & $\begin{array}{c}-0.120^{* * *} \\
(-3.169)\end{array}$ & $\begin{array}{c}-0.123^{* * *} \\
(-3.111)\end{array}$ & $\begin{array}{c}-0.118^{* * * *} \\
(-2.972)\end{array}$ \\
\hline Capital stock p.w. & $\begin{array}{c}-0.616 \\
(-1.001)\end{array}$ & $\begin{array}{c}-0.453 \\
(-0.653)\end{array}$ & $\begin{array}{c}0.105 \\
(0.142)\end{array}$ & $\begin{array}{c}0.208 \\
(0.277)\end{array}$ & $\begin{array}{c}-1.197 \\
(-1.119)\end{array}$ & $\begin{array}{c}-1.124 \\
(-1.080)\end{array}$ & $\begin{array}{c}-0.970 \\
(-0.953)\end{array}$ & $\begin{array}{c}-1.077 \\
(-0.940)\end{array}$ \\
\hline Labor productivity & $\begin{array}{c}5.484^{* * *} \\
(2.780)\end{array}$ & $\begin{array}{c}5.903^{* * *} \\
(2.740)\end{array}$ & $\begin{array}{c}6.108^{* * *} \\
(3.817)\end{array}$ & $\begin{array}{c}6.399 * * * \\
(2.891)\end{array}$ & $\begin{array}{c}13.75^{* * *} \\
(3.412)\end{array}$ & $\begin{array}{c}12.57^{* * *} \\
(3.391)\end{array}$ & $\begin{array}{c}13.19^{* * *} \\
(3.535)\end{array}$ & $\begin{array}{c}12.79 * * * \\
(3.417)\end{array}$ \\
\hline GDP per capita & $\begin{array}{c}-7.197^{* * * *} \\
(-3.244)\end{array}$ & $\begin{array}{c}-7.735^{* * * *} \\
(-3.121)\end{array}$ & $\begin{array}{c}-7.430^{* * * *} \\
(-3.792)\end{array}$ & $\begin{array}{c}-7.619^{* * * *} \\
(-3.089)\end{array}$ & $\begin{array}{c}-13.32 * * * \\
(-3.700)\end{array}$ & $\begin{array}{c}-12.59 * * * \\
(-3.776)\end{array}$ & $\begin{array}{c}-13.48^{* * * *} \\
(-3.946)\end{array}$ & $\begin{array}{c}-12.95^{* * * *} \\
(-3.911)\end{array}$ \\
\hline Fertility rates & $\begin{array}{c}-3.071 \\
(-0.909)\end{array}$ & $\begin{array}{c}-2.598 \\
(-0.756)\end{array}$ & $\begin{array}{l}-1.065 \\
(-0.280)\end{array}$ & $\begin{array}{l}-5.339 \\
(-1.533)\end{array}$ & $\begin{array}{c}-6.810 \\
(-1.592)\end{array}$ & $\begin{array}{c}-4.527 \\
(-1.109)\end{array}$ & $\begin{array}{l}-3.011 \\
(-0.753)\end{array}$ & $\begin{array}{l}-7.650 \text { * } \\
(-1.651)\end{array}$ \\
\hline Rule of law & $\begin{array}{l}5.704 * \\
(1.822)\end{array}$ & $\begin{array}{c}4.559 \\
(1.368)\end{array}$ & $\begin{array}{c}2.652 \\
(0.761)\end{array}$ & $\begin{array}{c}5.336 \\
(1.606)\end{array}$ & $\begin{array}{c}8.909 * * * \\
(2.931)\end{array}$ & $\begin{array}{c}7.709 * * * \\
(2.738)\end{array}$ & $\begin{array}{c}7.909 * * * \\
(2.700)\end{array}$ & $\begin{array}{c}9.220 * * * \\
(3.142)\end{array}$ \\
\hline GVC participation & $\begin{array}{c}3.179 * * * \\
(3.347)\end{array}$ & $\begin{array}{c}3.359 * * * \\
(3.496)\end{array}$ & $\begin{array}{c}7.267 * * * \\
(4.576)\end{array}$ & $\begin{array}{c}4.622 * * * \\
(4.392)\end{array}$ & $\begin{array}{l}1.679 * \\
(1.666)\end{array}$ & $\begin{array}{c}2.203^{* *} \\
(2.349)\end{array}$ & $\begin{array}{l}4.806^{* *} \\
(2.377)\end{array}$ & $\begin{array}{c}2.043 \\
(1.360)\end{array}$ \\
\hline \# of observations & 4445 & 4443 & 4434 & 4363 & 4643 & 4643 & 4624 & 4569 \\
\hline$\#$ of country-sector & 325 & 325 & 325 & 322 & 434 & 434 & 433 & 431 \\
\hline \# of instruments & 338 & 338 & 338 & 338 & 439 & 439 & 439 & 439 \\
\hline $\mathrm{AR}(2)$ & 0.309 & 0.294 & 0.284 & 0.299 & 0.350 & 0.357 & 0.319 & 0.375 \\
\hline Hansen (p) & 0.514 & 0.419 & 0.432 & 0.516 & 0.381 & 0.429 & 0.399 & 0.456 \\
\hline
\end{tabular}


Table 2. Cont.

\begin{tabular}{|c|c|c|c|c|c|c|c|c|}
\hline \multirow{4}{*}{$\begin{array}{c}\text { VARIABLES } \\
\text { GVC participation }\end{array}$} & \multicolumn{4}{|c|}{ Manufacturing } & \multicolumn{4}{|c|}{ Manufacturing } \\
\hline & BP_OECD & \multicolumn{2}{|c|}{ FP_OECD BP_K } & FP_K & BP_OECD & FP_OECD & BP_K & FP_K \\
\hline & $21.37^{* * *}$ & $27.75^{* * *}$ & $10.10 *$ & 4.771 & 11.73 & 11.20 & 7.484 & 1.893 \\
\hline & $(2.706)$ & $(3.728)$ & $(1.812)$ & $(1.043)$ & $(1.202)$ & $(1.452)$ & $(0.889)$ & $(0.327)$ \\
\hline \# of observations & 1698 & 1698 & 1698 & 1698 & 1453 & 1453 & 1453 & 1453 \\
\hline \# of country-sector & 121 & 121 & 121 & 121 & 135 & 135 & 135 & 135 \\
\hline \# of instruments & 133 & 133 & 133 & 133 & 136 & 136 & 136 & 136 \\
\hline $\mathrm{AR}(2)$ & 0.502 & 0.477 & 0.520 & 0.515 & 0.550 & 0.514 & 0.530 & 0.581 \\
\hline \multirow[t]{2}{*}{ Hansen $(p)$} & 0.376 & 0.531 & 0.378 & 0.326 & 0.267 & 0.266 & 0.233 & 0.307 \\
\hline & \multicolumn{4}{|c|}{ Services } & \multicolumn{4}{|c|}{ Services } \\
\hline GVC participation & $\begin{array}{l}1.255^{* *} \\
(2.575)\end{array}$ & $\begin{array}{c}0.905^{* *} \\
(2.024)\end{array}$ & $\begin{array}{c}-2.118 \\
(-1.452)\end{array}$ & $\begin{array}{l}1.246 \text { * } \\
(1.688)\end{array}$ & $\begin{array}{c}-0.301 \\
(-0.644)\end{array}$ & $\begin{array}{c}0.0415 \\
(0.0975)\end{array}$ & $\begin{array}{c}-0.548 \\
(-0.476)\end{array}$ & $\begin{array}{c}-0.309 \\
(-0.343)\end{array}$ \\
\hline \# of observations & 1982 & 1980 & 1971 & 1900 & 2422 & 2422 & 2411 & 2356 \\
\hline \# of country-sector & 147 & 147 & 147 & 144 & 227 & 227 & 226 & 224 \\
\hline \# of instruments & 133 & 133 & 133 & 133 & 211 & 211 & 211 & 211 \\
\hline $\operatorname{AR}(2)$ & 0.244 & 0.249 & 0.243 & 0.246 & 0.172 & 0.144 & 0.183 & 0.199 \\
\hline Hansen $(p)$ & 0.110 & 0.141 & 0.141 & 0.418 & 0.127 & 0.106 & 0.173 & 0.163 \\
\hline
\end{tabular}




\subsection{Total Factor Productivity Growth}

Since productivity channel has been commonly considered as one of the main channels for the impact of trade flows on growth and productivity spillovers based on trade in intermediate goods through which a sector can benefit from participation in GVCs, we undertake estimations for total factor productivity (TFP) growth in order to evaluate the role of productivity channel. The system GMM estimations for the TFP growth is reported in Table 3. Similar to the estimates for value-added growth, the significantly and positively estimated coefficients on all participation indices at the top panel of Table 3 for TiVA 2016 indicate that GVC participation is beneficial for overall sectors in terms of TFP growth. For TiVA 2018, all measures of GVCs participation except for the forward participation based on Koopman et al. [11] continue to become significant for the full data.

Country-level variables and time dummies are considered as exogenous. See also notes for Table 2.

We observe a qualitatively similar pattern for manufacturing and services for TiVA 2016, when we estimate the regressions for manufacturing and services separately. All indices except for the forward participation based on Koopman et al. [11] have significantly positive impacts on TFP growth for both sectors. In the later period, our estimates for manufacturing and services sectors considerably diverge, while our estimates for manufacturing are very similar to those for the earlier period. None of the estimates are significant for services for the later period.

Overall, our estimations clearly imply the decreasing trend of the impact of GVC participation on both output and TFP growth. A much lower effect of GVC participation on growth for the later period might be explained by the recent slowdown in global output and productivity growth rates. The expansion of GVCs in 1990s and 2000s has slowed down after the global financial crisis in 2008 [2,4]. During the same period, the annual growth rate of world trade decreases from 7\% (1994-2008) to 3\% (2012-2016), which is called as the "great trade collapse", and the annual growth rate of productivity decreases from $2 \%$ (1994-2008) to $1 \%$ after this crisis. The slowing expansion of GVCs is among most important factors accounting for this productivity slowdown [20]. The main reasons for the decreasing GVC expansion are decreasing global investment and growth, insufficient human capital and infrastructure and the lack of major liberalization initiatives, such as increasing protectionist sentiments and regulatory and institutional barriers [2,4]. Moreover, the bullwhip effect as a result of the latest crisis may hinder the enthusiasm of the firms toward global scale production and even may cause an interruption of trading relationships [35]. In particular, the world starts to witness the halt of international production fragmentation since 2011 [36], which cannot be investigated without the data covering the post-crisis years. If we run the regressions only for the overlapping parts of both datasets separately, our estimations for both value-added and TFP growth indicate that estimation results are substantially similar to each other for both of the periods. The estimations are not reported here, but are available upon request.

Given the fact that our country sample consists of mostly developed countries, these results are even more important. Our results also indicate that compared to the measures as shares of final demand, participation measures as shares of gross exports being regarded as more complex in nature have much less impact on growth rates. Note that complex forward participation of developed nations is mainly driven by their outward FDIs. Thus, this could be the sign of benefiting less in the later period probably due to the rising protectionist sentiments across the globe. Note that both backward and forward participations have significantly positive effects on output and productivity growth, which is extremely important because these results clearly imply that sectors benefit not only from exporting more through global value chains but also importing more through them. 
Table 3. Estimation Results for the TFP Growth.

\begin{tabular}{|c|c|c|c|c|c|c|c|c|}
\hline & \multicolumn{4}{|c|}{ TiVA 2016} & \multicolumn{4}{|c|}{ TiVA 2018} \\
\hline & \multicolumn{4}{|c|}{ All Sectors } & \multicolumn{4}{|c|}{ All Sectors } \\
\hline & (1) & $(2)$ & (3) & (4) & (1) & (2) & (3) & (4) \\
\hline VARIABLES & BP_OECD & FP_OECD & BP_K & FP_K & BP_OECD & FP_OECD & BP_K & FP_K \\
\hline Lagged TFP growth & $\begin{array}{l}-0.154 * * \\
(-2.045)\end{array}$ & $\begin{array}{l}-0.147^{*} \\
(-1.910)\end{array}$ & $\begin{array}{l}-0.150 * * \\
(-2.001)\end{array}$ & $\begin{array}{l}-0.133 * \\
(-1.683)\end{array}$ & $\begin{array}{c}-0.131 \\
(-1.594)\end{array}$ & $\begin{array}{c}-0.130 \\
(-1.583)\end{array}$ & $\begin{array}{l}-0.142 * \\
(-1.732)\end{array}$ & $\begin{array}{c}-0.124 \\
(-1.452)\end{array}$ \\
\hline Capital stock p.w. & $\begin{array}{c}-2.349 \\
(-1.422)\end{array}$ & $\begin{array}{l}-3.075^{* *} \\
(-1.987)\end{array}$ & $\begin{array}{c}-2.111 \\
(-1.436)\end{array}$ & $\begin{array}{c}-3.187 \\
(-1.510)\end{array}$ & $\begin{array}{c}-1.615 \\
(-0.580)\end{array}$ & $\begin{array}{c}-2.289 \\
(-0.777)\end{array}$ & $\begin{array}{c}-2.895 \\
(-1.287)\end{array}$ & $\begin{array}{c}-3.277 \\
(-1.083)\end{array}$ \\
\hline Labor productivity & $\begin{array}{c}7.853^{* * *} \\
(3.168)\end{array}$ & $\begin{array}{c}8.453^{* * *} \\
(3.387)\end{array}$ & $\begin{array}{c}8.292^{* * *} \\
(3.351)\end{array}$ & $\begin{array}{c}8.780 * * * \\
(2.861)\end{array}$ & $\begin{array}{l}11.74^{* *} \\
(2.520)\end{array}$ & $\begin{array}{c}11.92^{* * *} \\
(2.944)\end{array}$ & $\begin{array}{c}13.38^{* * *} \\
(3.154)\end{array}$ & $\begin{array}{c}11.61^{* * *} \\
(2.909)\end{array}$ \\
\hline GDP per capita & $\begin{array}{c}-8.547^{* * * *} \\
(-2.943)\end{array}$ & $\begin{array}{c}-8.524^{* * * *} \\
(-2.912)\end{array}$ & $\begin{array}{c}-8.014^{* * * *} \\
(-2.922)\end{array}$ & $\begin{array}{c}-9.051^{* * * *} \\
(-3.768)\end{array}$ & $\begin{array}{c}-9.776^{* *} \\
(-2.469)\end{array}$ & $\begin{array}{c}-9.969 * * * \\
(-2.608)\end{array}$ & $\begin{array}{c}-10.03^{* * * *} \\
(-2.722)\end{array}$ & $\begin{array}{c}-8.982 * * * * \\
(-2.719)\end{array}$ \\
\hline Fertility rates & $\begin{array}{c}0.194 \\
(0.0450)\end{array}$ & $\begin{array}{c}0.0747 \\
(0.0187)\end{array}$ & $\begin{array}{c}0.330 \\
(0.0866)\end{array}$ & $\begin{array}{c}-2.211 \\
(-0.558)\end{array}$ & $\begin{array}{l}-4.347 \\
(-1.330)\end{array}$ & $\begin{array}{c}-3.655 \\
(-1.121)\end{array}$ & $\begin{array}{l}-2.272 \\
(-0.636)\end{array}$ & $\begin{array}{c}-7.395^{* * * *} \\
(-2.618)\end{array}$ \\
\hline Rule of law & $\begin{array}{c}4.933 \\
(1.321)\end{array}$ & $\begin{array}{c}4.436 \\
(1.160)\end{array}$ & $\begin{array}{c}3.219 \\
(0.888)\end{array}$ & $\begin{array}{l}6.366^{* *} \\
(2.204)\end{array}$ & $\begin{array}{c}3.590 \\
(1.165)\end{array}$ & $\begin{array}{c}4.106 \\
(1.454)\end{array}$ & $\begin{array}{c}2.239 \\
(0.729)\end{array}$ & $\begin{array}{l}4.255^{*} \\
(1.875)\end{array}$ \\
\hline GVC participation & $\begin{array}{c}3.795^{* * *} \\
(5.266)\end{array}$ & $\begin{array}{c}3.090 * * * \\
(4.290)\end{array}$ & $\begin{array}{c}6.039 * * * \\
(4.660)\end{array}$ & $\begin{array}{l}2.350 * \\
(1.721)\end{array}$ & $\begin{array}{l}2.260 \text { ** } \\
(2.362)\end{array}$ & $\begin{array}{c}1.985^{* * *} \\
(2.872)\end{array}$ & $\begin{array}{c}5.441 * * * \\
(2.740)\end{array}$ & $\begin{array}{c}1.476 \\
(1.022)\end{array}$ \\
\hline \# of observations & 3007 & 3007 & 3003 & 2992 & 3564 & 3564 & 3545 & 3534 \\
\hline \# of country-sector & 261 & 261 & 261 & 258 & 354 & 354 & 353 & 353 \\
\hline \# of instruments & 242 & 242 & 242 & 242 & 316 & 316 & 316 & 316 \\
\hline $\mathrm{AR}(2)$ & 0.533 & 0.564 & 0.553 & 0.630 & 0.987 & 0.971 & 0.941 & 0.940 \\
\hline Hansen (p) & 0.198 & 0.233 & 0.206 & 0.287 & 0.177 & 0.120 & 0.148 & 0.164 \\
\hline
\end{tabular}


Table 3. Cont.

\begin{tabular}{|c|c|c|c|c|c|c|c|c|}
\hline \multirow[b]{2}{*}{ VARIABLES } & \multicolumn{4}{|c|}{ Manufacturing } & \multicolumn{4}{|c|}{ Manufacturing } \\
\hline & BP_OECD & FP_OECD & BP_K & FP_K & BP_OECD & FP_OECD & BP_K & FP_K \\
\hline \multirow[t]{2}{*}{ GVC participation } & $21.23^{* *}$ & $18.59 * *$ & $15.33^{*}$ & -1.696 & $15.84^{* *}$ & $10.01 *$ & $12.71^{* *}$ & 6.097 \\
\hline & $(2.245)$ & $(2.119)$ & $(1.873)$ & $(-0.257)$ & $(2.479)$ & $(1.703)$ & $(2.304)$ & $(0.776)$ \\
\hline \# of observations & 1337 & 1337 & 1337 & 1337 & 1282 & 1282 & 1282 & 1282 \\
\hline \# of country-sector & 109 & 109 & 109 & 109 & 122 & 122 & 122 & 122 \\
\hline \# of instruments & 133 & 133 & 133 & 133 & 136 & 136 & 136 & 136 \\
\hline $\mathrm{AR}(2)$ & 0.517 & 0.510 & 0.551 & 0.555 & 0.836 & 0.868 & 0.866 & 0.914 \\
\hline \multirow[t]{2}{*}{ Hansen $(p)$} & 0.755 & 0.773 & 0.851 & 0.799 & 0.678 & 0.600 & 0.603 & 0.610 \\
\hline & \multicolumn{4}{|c|}{ Services } & \multicolumn{4}{|c|}{ Services } \\
\hline GVC participation & $6.009^{* * *}$ & $2.841^{* *}$ & $5.290 * *$ & 0.409 & 0.297 & 0.685 & 0.652 & 1.299 \\
\hline & (3.096) & $(2.373)$ & $(2.572)$ & $(1.044)$ & $(0.409)$ & $(1.045)$ & $(0.468)$ & $(1.029)$ \\
\hline \# of observations & 1214 & 1214 & 1210 & 1199 & 1738 & 1738 & 1727 & 1716 \\
\hline \# of country-sector & 110 & 110 & 110 & 107 & 176 & 176 & 175 & 175 \\
\hline \# of instruments & 131 & 131 & 131 & 131 & 174 & 174 & 174 & 174 \\
\hline $\operatorname{AR}(2)$ & 0.501 & 0.186 & 0.121 & 0.125 & 0.731 & 0.873 & 0.846 & 0.716 \\
\hline Hansen $(p)$ & 0.866 & 0.878 & 0.930 & 0.952 & 0.242 & 0.289 & 0.243 & 0.319 \\
\hline
\end{tabular}

Note: All sector-level variables are regarded as endogenous or predetermined variables and their three lags are used as instruments for the former period (seven lags for the latter period). For the manufacturing and services regressions, lags used in the "gmmstyle" option ranges between one and three. 


\section{Conclusions}

This study investigates the impact of sectoral participation in GVCs calculated by two different methods on sectoral value-added growth and TFP growth. Our dataset includes 26 EU countries and the USA, with 21 sectors for the first dataset (TiVA 2016) and 28 sectors for the second dataset (TiVA 2018). The empirical model is estimated for the indices of the years 1995-2011 from TiVA 2016 edition and of the years 2005-2015 from TiVA 2018 edition by using the system GMM method.

Our dynamic panel data estimates for sectoral value-added growth indicate that participation in GVCs has positive impacts for the overall sample. Considering the parameter heterogeneity, we repeat our estimations for manufacturing and services separately. We have considerably similar results for manufacturing and services sectors though. Although participation in GVCs raises output growth in both manufacturing and services sectors for the earlier period, it does not have any significant effect on both sectors at the later period. Given that total factor productivity growth is one of the main components of output growth, we then investigate the relationship between GVCs participation and sectoral productivity growth. Like the estimates for output growth, GVC participations have a significantly positive effect on TFP growth for the overall sample. Both backward and forward participations have considerable positive impacts on sectoral TFP growth for both the periods. For services, participation in GVCs has the significantly positive impact on TFP growth only for the earlier period though.

Overall, our results also imply that there are decreasing gains from GVC participation in the later period and this conclusion is valid for both sectoral value-added and TFP growth estimations. The global productivity and output slowdown after the latest global crisis may be one of the explanations for these results. It seems that both manufacturing and services are considerably affected from the changing pattern of global trade after the 2008 crisis. Rising protectionist sentiments started after the crisis and the bullwhip effects observed along the chains, as mentioned above, lead to inefficiencies in the activities of GVCs. Our results are, thus, consistent with the changing role of GVCs on output and productivity growth after the 2008 crisis.

Our conclusions have important policy implications, especially for countries increasingly integrated to the value chains. Given the deteriorating conditions in the global economic environment due to the global COVID-19 pandemic and the emerging economic recession, our results clearly imply that countries with higher participation in GVCs will experience lower output and productivity growth. Countries ought to be aware of the contagious effects of participating in value chains, probably due to the prevailing demand and supply shocks. Therefore, countries should take necessary precautionary measures to mitigate the adverse effects, as discussed above. To effectively cope with the adverse effects of declining value chains, researchers need to analyze the nexus with the more disaggregated data, as one limitation of our study is that the current state of the aggregation level of inter-country input-output tables do not allow the calculation of further disaggregated participation rates for most of the countries.

Author Contributions: All authors have contributed equally. All authors have read and agreed to the published version of the manuscript.

Funding: This research received no external funding.

Acknowledgments: The first author acknowledges support from the Turkish Academy of Sciences.

Conflicts of Interest: The authors declare no conflict of interest. 


\section{Appendix A}

Table A1. Industry Matching between EU KLEMS and OECD TiVA.

\begin{tabular}{|c|c|c|c|c|}
\hline TiVA 2016 & TiVA 2018 & EU KLEMS & EU KLEMS DESCRIPTIONS & Main Category \\
\hline C01T05 & D01T03 & A & AGRICULTURE, FORESTRY AND FISHING & Other production \\
\hline C10T14 & D05T09 & $\mathrm{B}$ & MINING AND QUARRYING & Other production \\
\hline C15T16 & D10T12 & $10-12$ & Food products, beverages and tobacco & Manufacturing \\
\hline C17T19 & D13T15 & $13-15$ & Textiles, wearing apparel, leather and related products & Manufacturing \\
\hline- & D16T18 & $16-18$ & $\begin{array}{l}\text { Wood and paper products; printing and reproduction of } \\
\text { recorded media }\end{array}$ & Manufacturing \\
\hline $\mathrm{C} 23$ & D19 & 19 & Coke and refined petroleum products & Manufacturing \\
\hline $\mathrm{C} 24$ & D20T21 & $20-21$ & Chemicals and chemical products & Manufacturing \\
\hline C27T28 & D24T25 & $24-25$ & $\begin{array}{l}\text { Basic metals and fabricated metal products, except } \\
\text { machinery and equipment }\end{array}$ & Manufacturing \\
\hline С30Т33 & D26T27 & $26-27$ & Electrical and optical equipment & Manufacturing \\
\hline $\mathrm{C} 29$ & D28 & 28 & Machinery and equipment n.e.c. & Manufacturing \\
\hline С34T35 & D29T30 & $29-30$ & Transport equipment & Manufacturing \\
\hline C36T37 & D31T33 & $31-33$ & $\begin{array}{l}\text { Other manufacturing; repair and installation of machinery } \\
\text { and equipment }\end{array}$ & Manufacturing \\
\hline- & D35T39 & D-E & ELECTRICITY, GAS AND WATER SUPPLY & Other production \\
\hline C45 & D41T43 & $\mathrm{F}$ & CONSTRUCTION & Other production \\
\hline C50T52 & D45T47 & G & $\begin{array}{l}\text { WHOLESALE AND RETAIL TRADE; REPAIR OF } \\
\text { MOTOR VEHICLES AND MOTORCYCLES }\end{array}$ & Services \\
\hline- & D49T53 & $\mathrm{H}$ & TRANSPORTATION AND STORAGE & Services \\
\hline C55 & D55T56 & I & ACCOMMODATION AND FOOD SERVICE ACTIVITIES & Services \\
\hline- & D58T60 & $58-60$ & Publishing, audiovisual and broadcasting activities & Services \\
\hline- & D61 & 61 & Telecommunications & Services \\
\hline $\mathrm{C} 72$ & D62T63 & $62-63$ & IT and other information services & Services \\
\hline C65T67 & D64T66 & K & FINANCIAL AND INSURANCE ACTIVITIES & Services \\
\hline $\mathrm{C} 70$ & D68 & $\mathrm{L}$ & REAL ESTATE ACTIVITIES & Services \\
\hline- & D69T82 & $\mathrm{M}-\mathrm{N}$ & $\begin{array}{l}\text { PROFESSIONAL, SCIENTIFIC, TECHNICAL, } \\
\text { ADMINISTRATIVE AND SUPPORT SERVICE } \\
\text { ACTIVITIES }\end{array}$ & Services \\
\hline $\mathrm{C} 75$ & D84 & $\mathrm{O}$ & $\begin{array}{l}\text { Public administration and defence; compulsory social } \\
\text { security }\end{array}$ & Services \\
\hline $\mathrm{C} 80$ & D85 & $\mathrm{P}$ & Education & Services \\
\hline $\mathrm{C} 85$ & D86T88 & Q & Health and social work & Services \\
\hline- & D90T96 & R-S & $\begin{array}{l}\text { ARTS, ENTERTAINMENT, RECREATION AND OTHER } \\
\text { SERVICE ACTIVITIES }\end{array}$ & Services \\
\hline C95 & D97T98 & $\mathrm{T}$ & $\begin{array}{l}\text { Activities of households as employers; undifferentiated } \\
\text { goods- and services-producing activities of households for } \\
\text { own use }\end{array}$ & Services \\
\hline
\end{tabular}

Notes: To match industries across datasets, we use documents such as "industry breakdown for the 2016 TiVA Indicators" [23], "list of industries for TiVA 2018" [14], "the notes for the differences between TiVA 2016 and TiVA 2018" [14], "EU KLEMS industry list" [22] and "Eurostat SNA NACE Rev.2 (ISIC Rev.4) A*64 to A*10 hierarchy" [37]. 
Table A2. List of Countries.

\begin{tabular}{|c|c|c|c|c|c|c|c|c|}
\hline 1 & AUS & Australia & 23 & MEX & Mexico & 45 & HRV & Croatia \\
\hline 2 & AUT & Austria & 24 & NLD & Netherlands & 46 & CYP & Cyprus \\
\hline 3 & BEL & Belgium & 25 & NZL & New Zealand & 47 & IND & India \\
\hline 4 & CAN & Canada & 26 & NOR & Norway & 48 & IDN & Indonesia \\
\hline 5 & CHL & Chile & 27 & POL & Poland & 49 & HKG & Hong Kong (China) \\
\hline 6 & CZE & Czech Republic & 28 & PRT & Portugal & 50 & KAZ & Kazakhstan \\
\hline 7 & DNK & Denmark & 29 & SVK & Slovak Republic & 51 & MYS & Malaysia \\
\hline 8 & EST & Estonia & 30 & SVN & Slovenia & 52 & MLT & Malta \\
\hline 9 & FIN & Finland & 31 & ESP & Spain & 53 & MAR & Morocco \\
\hline 10 & FRA & France & 32 & SWE & Sweden & 54 & PER & Peru \\
\hline 11 & DEU & Germany & 33 & $\mathrm{CHE}$ & Switzerland & 55 & PHL & Philippines \\
\hline 12 & GRC & Greece & 34 & TUR & Turkey & 56 & ROU & Romania \\
\hline 13 & HUN & Hungary & 35 & GBR & United Kingdom & 57 & RUS & Russian Federation \\
\hline 14 & ISL & Iceland & 36 & USA & United States & 58 & SAU & Saudi Arabia \\
\hline 15 & IRL & Ireland & 37 & ARG & Argentina & 59 & SGP & Singapore \\
\hline 16 & ISR & Israel & 38 & BRA & Brazil & 60 & ZAF & South Africa \\
\hline 17 & ITA & Italy & 39 & BRN & $\begin{array}{c}\text { Brunei } \\
\text { Darussalam }\end{array}$ & 61 & TWN & Chinese Taipei \\
\hline 18 & JPN & Japan & 40 & BGR & Bulgaria & 62 & THA & Thailand \\
\hline 19 & KOR & Korea & 41 & KHM & Cambodia & 63 & TUN & Tunisia \\
\hline 20 & LVA & Latvia & 42 & $\mathrm{CHN}$ & China & 64 & VNM & Viet Nam \\
\hline 21 & LTU & Lithuania & 43 & $\mathrm{COL}$ & Colombia & & & \\
\hline 22 & LUX & Luxembourg & 44 & CRI & Costa Rica & & & \\
\hline
\end{tabular}

Notes: All countries above are covered in TiVA 2018 edition. TiVA 2016 edition does not include Kazakhstan. Countries in bold are included in EU KLEMS basic files (EU28 and USA). However, two countries (Belgium and Croatia) are missing in capital file of EU KLEMS. Thus, our analysis basically covers 26 EU countries and the USA.

\section{References}

1. UNCTAD. World Investment Report: Global Value Chains: Investment and Trade for Development; UN Publication: Geneva, Switzerland, 2013.

2. World Development Report. Trading for Development in the Age of Global Value Chains; The World Bank: Washington, DC, USA, 2020; Available online: https:/www.worldbank.org/en/publication/wdr2020 (accessed on 5 April 2020).

3. Fessehaie, J.; Morris, M. Global Value Chains and Sustainable Development Goals: What Role for Trade and Industrial Policies? International Centre for Trade and Sustainable Development (ICTSD): Geneva, Switzerland, 2018; Available online: https://www.ictsd.org/sites/default/files/research/ictsd_gvc_synthesis_report_final_0.pdf (accessed on 5 April 2020).

4. Todo, Y.; Akman, M.S.; Hattori, T.; Saha, S.; Volchkova, N. Expanding and Restructuring Global Value Chains for Sustainable and Inclusive Growth. Think20 (T20) Policy Briefs 2019. Available online: https: //t20japan.org/policy-brief-expanding-restructuring-gvc-sustainable-growth/ (accessed on 5 April 2020).

5. UNIDO. Global Value Chains and Development: UNIDO's Support towards Inclusive and Sustainable Industrial Development; United Nations Industrial Development Organization: Vienna, Austria, 2015; Available online: https://www.unido.org/sites/default/files/2016-03/GVC_REPORT_FINAL_0.PDF (accessed on 5 April 2020).

6. Ferrantino, M.J.; Taglioni, D. Global Value Chains in the Current Trade Slowdown; Economic Premise Note Series 137; The World Bank Poverty Reduction and Economic Management Network (PREM): Washington, DC, USA, 2014; Available online: http://documents.worldbank.org/curated/en/971291468149948311/Global-valuechains-in-the-current-trade-slowdown (accessed on 5 April 2020). 
7. Altomonte, C.; Di Mauro, F.; Ottaviano, G.; Rungi, A.; Vicard, V. Global Value Chains during Great Trade Collapse: A Bullwhip Effect? European Central Bank Working Paper Series No 1412; European Central Bank: Frankfurt am Main, Germany, 2012; Available online: https://www.ecb.europa.eu/pub/pdf/scpwps/ecbwp1412.pdf (accessed on 5 April 2020).

8. Rodrik, D. New Technologies, Global Value Chains, and Developing Economies. National Bureau of Economic Research No. 25164. 2018. Available online: https://www.nber.org/papers/w25164 (accessed on 5 April 2020).

9. Fagerberg, J.; Lundwall, B.-A.; Srholec, M. Global Value Chains, National Innovation Systems and Economic Development. Eur. J. Dev. Res. 2018, 30, 533-556. [CrossRef]

10. OECD. Global Value Chains and Trade in Value-Added: An Initial Assessment of the Impact on Jobs and Productivity; OECD Trade Policy Papers No 190; OECD Publishing: Paris, France, 2016. [CrossRef]

11. Koopman, R.; Powers, W.; Wang, Z.; Wei, S.-J. Give Credit Where Credit Is Due: Tracing Value Added in Global Production Chains. National Bureau of Economic Research (NBER) Working Paper No 16426, 2010 (Revised September 2011). Available online: http://www.nber.org/papers/w16426.pdf (accessed on 6 November 2018).

12. Hummels, D.; Ishii, J.; Yi, K. The Nature and Growth of Vertical Specialization in World Trade. J. Int. Econ. 2001, 54, 75-96. [CrossRef]

13. Wang, Z.; Wei, S.-J.; Yu, X.; Zhu, K. Measures of Participation in Global Value Chains and Global Business Cycles. National Bureau of Economic Research (NBER) Working Paper No 23222. 2017. Available online: http://www.nber.org/papers/w23222.pdf (accessed on 6 November 2018).

14. OECD. Trade in Value Added. OECD-WTO: Statistics on Trade in Value Added (Database). 2019. Available online: https://doi.org/10.1787/data-00648-en (accessed on 15 February 2019).

15. Yanikkaya, H.; Altun, A. The Impact of Participation in Export Value Chains on TFP Growth. Ege Acad. Rev. 2018, 19, 119-129.

16. Ignatenko, A.; Raei, F.; Mircheva, B. Global Value Chains: What Are the Benefits and Why Do Countries Participate? IMF Working Paper No WP/19/18. 2019. Available online: https://www.imf.org/en/Publications/WP/Issues/2019/01/18/Global-Value-Chains-What-are-theBenefits-and-Why-Do-Countries-Participate-46505 (accessed on 19 March 2019).

17. Formai, S.; Caffarelli, F.P. Quantifying the Productivity Effects of Global Value Chains. Temi di Discussione Working Papers No 1075; Bank of Italy. 2016. Available online: https://www.bancaditalia.it/pubblicazioni/ temi-discussione/2016/2016-1075/index.html?com.dotmarketing.htmlpage.language=1 (accessed on 5 March 2019).

18. Kowalski, P.; Gonzalez, J.L.; Ragoussis, A.; Ugarte, C. Participation of Developing Countries in Global Value Chains: Implications for Trade and Trade-Related Policies; OECD Trade Policy Papers No 179; OECD Publishing: Paris, France, 2015. [CrossRef]

19. Kummritz, V. Global Value Chains: Benefiting the Domestic Economy? IHEID Working Papers 02-2015; Economics Section, the Graduate Institute of International Studies. 2015. Available online: http://repec. graduateinstitute.ch/pdfs/Working_papers/HEIDWP02-2015.pdf (accessed on 23 March 2019).

20. Constantinescu, C.; Mattoo, A.; Ruta, M. Does Vertical Specialization Increase Productivity? World Econ. 2019, 42, 2385-2402. [CrossRef]

21. Kordalska, A.; Parteka, A.; Wolszczak-Derlacz, J. Global Value Chains and Productivity Gains: A Cross-Country Analysis. Wars. Sch. Econ. Coll. Econ. Anal. (CEA) Ann. 2016, 41, 11-27.

22. Jaeger, K. EU KLEMS Growth and Productivity Accounts 2017 Release (Revised July 2018)—Description of Methodology and General Notes. The Conference Board. 2018. Available online: www.euklems.net (accessed on 6 January 2019).

23. WTO/OECD. Trade in Value Added (Edition 2016). OECD-WTO: Statistics on Trade in Value Added (Database). 2016. Available online: https://doi.org/10.1787/2644abe4-en (accessed on 15 February 2019).

24. R Core Team. R: A Language and Environment for Statistical Computing; R Foundation for Statistical Computing: Vienna, Austria, 2019; Available online: https://www.R-project.org/ (accessed on 6 January 2019).

25. Eurostat. Exchange and Interest Rates. 2019. Available online: https://ec.europa.eu/eurostat/web/exchangeand-interest-rates/data/database (accessed on 11 February 2019).

26. World Bank. World Development Indicators (Updated in 24 January 2019). 2019. Available online: https://datacatalog.worldbank.org/dataset/world-development-indicators (accessed on 6 March 2019). 
27. Kaufmann, D.; Kraay, A.; Mastruzzi, M. The Worldwide Governance Indicators: Methodology and Analytical Issues. Hague J. Rule Law 2011, 3, 220-246. [CrossRef]

28. Baum, C.F.; Schaffer, M.E.; Stillman, S. Instrumental Variables and GMM: Estimation and Testing. Stata J. 2003, 3, 1-31. [CrossRef]

29. Arellano, M.; Bond, S. Some Tests of Specification for Panel Data: Monte Carlo Evidence and an Application to Employment Equations. Rev. Econ. Stud. 1991, 58, 277-297. [CrossRef]

30. Arellano, M.; Bover, O. Another Look at the Instrumental Variable Estimation of Error-components Models. J. Econom. 1995, 68, 29-51. [CrossRef]

31. Blundell, R.; Bond, S. Initial Conditions and Moment Restrictions in Dynamic Panel Data Models. J. Econom. 1998, 87, 115-143. [CrossRef]

32. Roodman, D. How to do xtabond2: An Introduction to Difference and System GMM in Stata. Stata J. 2009, 9, 86-136. [CrossRef]

33. Baum, C.F.; Schaffer, M.E.; Stillman, S. Enhanced Routines for Instrumental Variables/Generalized Method of Moments Estimation and Testing. Stata J. 2007, 7, 465-506. [CrossRef]

34. Windmeijer, F. A Finite Sample Correction for the Variance of Linear Efficient Two-Step GMM Estimators. J. Econom. 2005, 126, 25-51. [CrossRef]

35. Zavacka, V. The Bullwhip Effect and the Great Trade Collapse. European Bank for Reconstruction and Development Working Papers No 148. 2012. Available online: https://www.ebrd.com/downloads/research/ economics/workingpapers/wp0148.pdf (accessed on 5 April 2020).

36. Timmer, M.P.; Los, B.; Stehrer, R.; de Vries, G.J. An Anatomy of the Global Trade Slowdown Based on the WIOD 2016 Release. GGDC Research Memoranda No 162, University of Groningen. 2016. Available online: www.ggdc.net/publications/memorandum/gd162.pdf (accessed on 5 April 2020).

37. OECD. STAN Industry ISIC Rev. 4. STAN: OECD Structural Analysis Statistics (Database). 2019. Available online: http://www.oecd.org/sti/ind/stanstructuralanalysisdatabase.htm (accessed on 15 February 2019).

(C) 2020 by the authors. Licensee MDPI, Basel, Switzerland. This article is an open access article distributed under the terms and conditions of the Creative Commons Attribution (CC BY) license (http://creativecommons.org/licenses/by/4.0/). 